\title{
Debate on the Teaching of History: Historical Epistemology Meets Nationalist Narrative
}

\section{Bruce Curtis}

Canadians federally and residents of Quebec provincially are being exposed to major attempts to rewrite history and to rework historical memory. Federally, such attempts changed course and intensity after the Conservative minority government took office in 2006 and began to militarize memory, while moving to eliminate large portions of the country's scientific and historical research infrastructure. In Quebec, shifting versions of nationalist memory have a more complex pedigree. Éthier, Cardin and Lefrançois' "Cris et chuchotements" is a stimulating polemic directed against the project of people they characterize as ethnic nationalists to ensure that history teaching in Quebec high schools, and official historical memory more generally, support a vision of the "Quebec nation" and its as-yet-unrealized destiny of political independence. ${ }^{1}$

In their essay, Éthier, Cardin and Lefrançois show that the teaching of history in Quebec's school system has been a political enterprise since it began. Its objectives and substance have followed the various transformations in Quebec's internal politics and in the province's relation to the rest of the federation. Under the hegemony of the Catholic Church, the boundaries of the French Canadian community were defined in ethnic-religious terms rather than in terms of location in sovereign territory. School history teaching focussed on a grand narrative of triumphant colonisation by heroes of the faith in the service of Divine Providence. With the ending of the Church's hegemony, the boundaries of the community were redrawn as those of the territory of Quebec. Under the Lesage and Bourassa Liberals, Quebec was still seen as the nursery of a French reality for Canada, even if school history turned to focus on a secular Quebec society. However, in opposition to the Trudeau Liberal project of translating the pan-Canadian Catholic vision into a national civil FrenchCanadianism, the first Parti Québécois (PQ) government of Réné Lévesque famously wrote off French-Canadians living outside Quebec as doomed to cultural extinction. History teaching was caught up in the ongoing conflict between the Quebec Liberal party's project for heightened provincial autonomy within the Canadian federation 
and the Parti Québécois' project for an independent Quebec state promoting the French language and Quebec's “cultural traditions.”

The sovereignty project under the first PQ government had strongly social democratic dimensions, but these were largely abandoned after the 1980 sovereignty referendum. Although Quebec remains one of Canada's most progressive provinces in many areas of social policy, both the Liberal party and the PQ have oriented government towards competitiveness, "responsibilization" and austerity, all of which sustain class difference by redistributing wealth upwards, and some of which aim explicitly at grinding the faces of the poor. Matters are made more complex by the rise of the NDP, which associates its mild social democracy with federalism. At the same time, the immigration stream has come to include more people seen by some Francophones as culturally distant and menacing, strengthening xenophobic sentiment. ${ }^{2}$ As André Lecours has pointed out, the disappearance of differences in political economic policy between the two main provincial political parties gives heightened importance to issues of language and culture — including memory and invented tradition — for the pro-sovereignty project. ${ }^{3}$

The current Quebec pedagogy debate began around a secondary school curriculum reform that included a course on History and Education for Citizenship, composed after extensive consultation with history teachers and professional university historians. Three core dimensions of the course stimulated debate and criticism. First, it embodied history teachers' awareness that it is deeply tedious to teach and deadly boring for most students to learn history as a fixed set of names and dates. Second, it embodied an epistemological approach: the understanding of most academic historians that there is no single story to be told about the past, and thus the development of historical literacy depends on the critical evaluation of claims-making practices. Third, it embodied assumptions of one variation on civic education: that is, in principle, all competent residents of the provincial territory are equal participants in civil life and the teaching of history should extend and develop the capacities of all citizens for informed and critical participation in that life. That position tends also to imply the existence of many different histories.

The first draft of the course thus included a student-centred method of instruction, in which teachers would exercise considerable autonomy over the choice of subject matter. They would work to develop their students' engagement with concepts and their critical skills of investigation by working with and through types of historical documents, records, and media. They would not impose a grand historical narrative. The conventional focus on the great political events having shaped the nation would be abandoned as a necessary point of departure. One can argue that such an approach increases the possibilities for teachers and students to engage historically with events of moment as these unfold.

Éthier, Cardin and Lefrançois describe the broad spectrum of attacks on the reformed curriculum, which came both from the political left and right. In the absence of a definitive narrative, the curriculum was said to undermine the role of struggle in history - national struggle for some, class struggle for others - and to aim instead at a cozy consensus. The curriculum was "post-modern," which meant to its 
critics that since it taught about no events in particular, it taught about anything, and hence about nothing important. ${ }^{4}$ Many committed nationalists on the left and right, including professional historians, insisted that a history curriculum should include the study of key events in the shaping of Quebec society. Although inflected in a variety of ways, the proposed list included at least events in 1760, 1837, 1840, and 1867. Some commentators added early events of "discovery" and colonization, and later events, such as the Conscription Crisis of World War One, and the "night of the long knives" during the constitutional meetings of $1982 . .^{5}$ A variety of political stances on the national question could and did insist that formative events in Quebec history needed to be included in high school history teaching. A revised version of the curriculum then restored the obligation of teachers to cover "key events," while attempting to preserve the enquiry-based model.

I am not placed to comment on the substance of this curriculum nor on its operation in practice. Éthier, Cardin and Lefrançois point out that debate continues because many militant nationalists oppose any history teaching that does not present students with a clear recitation of the struggles of the Quebec "nation" for self-realization. That position, they show us as well, recycles a narrative of French-Canadian victimization and it is often paired explicitly to the demand that recent immigrants to Quebec be made to learn this version of the history of Quebec in order to further their assimilation to a dominant "national" culture. Other critics insist that historically-literate citizens should learn about the key events and struggles that have shaped the present situation.

But critical enquiry-based teaching and learning are agnostic about everything except the value of critical enquiry. In the domain of enquiry, systematic doubt obtains, and received wisdoms of all sorts are subject to it. Thus, ultimately, frozen narratives of the real truth of history and critical enquiry-based learning are irreconcilable. Some pro-sovereignty voices insist vehemently that they can be reconciled, but the sterility of such insistence is perfectly evident in early iterations of the curriculum debate. ${ }^{6}$ On the other hand, while high school history teachers can promote critical enquiry-based learning for their students, they must use some particular materials to do so and hence must confront their students with some narrative or other about some events. Well-trained subject specialists could use events of moment as the subject of enquiry, but it is likely that the run-of-the mill teacher will use readily available curriculum materials, and these in turn are likely to contain conventional narratives. From my point of view, the choice of any particular set of materials - providing that it has some minimal degree of substance - is less important than the performance of the work of critical enquiry conducted upon it. Thus, for instance, a narrative that claims to recount the necessarily true history of the Quebec people could serve as curriculum material, provided that students could learn to apply techniques of historical critique to it. In what follows, I consider what such an encounter might be like.

\section{The "Patriots' War"}

One striking dimension of contemporary Quebec cultural politics lies in the energetic efforts of nationalist historians to multiply and diversify the commemoration 
and celebration of key events in "the national past." Again, given the abandonment by most PQ-affiliated nationalists of any pretence at a social democratic project, cultural and historical markers of national difference have acquired a dramatically heightened importance in the struggle for a national state. A variety of attempts at inventing a distinctive national political tradition and memory are in evidence, first among them the re-invention of the Rebellion of 1837 as "the patriots' war."

In 2002, the PQ government designated the Monday before May 25 each year as "National Patriots' Day." A May 24 holiday is a relic of British colonial domination, first intended to mark the birthday of Queen Victoria, although in much of English Canada it has become better known as "May Two-Four," praise for beer and sunburn. But for male French Lower Canadian politicians (to paraphrase Allan Greer slightly) "the Queen was a whore," a woman in public and hence a public woman, the immoral figurehead of imperialist power. During the first attempts at official expression of grief for the death of her father and celebration of her coronation in the summer of 1837 , petty-bourgeois political leaders stormed out of parish churches or ostentatiously turned their backs on the altar and refused to participate in processions. ${ }^{8}$ When Victoria Day later became a federal holiday, Quebec governments chose instead to celebrate Dollard des Ormeaux, the brave young man who supposedly died saving seventeenth-century Montreal from the Iroquois. But celebrating great Indian-fighters became politically awkward, to say the least, by the end of the millennium: hence National Patriots' Day.

Rebellion events and personalities have been detailed in a bulimic outpouring of materials over the last two decades, and public space is marked and decorated in their honour - the creation of Place Louis-Joseph-Papineau in St-Denis is a recent example - in what amounts to a process of memory sacralization. ${ }^{9}$ In anticipation of 2013's National Patriots' Day Le Devoir, the province's independent newspaper, carried an illustrated 16-page pamphlet called Journal le Fleurdelisé, meant to inform about and to encourage celebration of a vision of 1837. Le Fleurdelisé is produced by a group calling itself the Mouvement national des Québécoises et Québécois, among whose leading members are many of the nationalist voices active in the curriculum debate and criticized in Éthier, Cardin and Lefrançois's polemic. ${ }^{10}$ The organization's president is the history professor Gilles Laporte, crowned patriot of the year in 2010, whose longstanding fascination with Rebellion history has resulted in a useful inventory of political meetings and speeches with many vignettes of individual biography, called Patriotes et Loyaux. Laporte has also maintained a website, where those with an interest in genealogy can learn if they have relatives who were active in events in 1837-8. His rousing speeches in Patriots' Day celebrations commonly denounce the Canadian state as born out of hatred and terror directed at the rights of FrenchCanadians. ${ }^{11}$ With some other publishing houses, the Septentrion press has been tireless in producing a wave of Rebellion literature as well, re-editing older publications, and adding work that profiles Rebellion participants by occupation, that details political party organization and that attempts to rehabilitate such flip-flopping political figures as the Swiss adventurer Amury Girod. Although most of this work carries a 
heavily nationalist interpretation, it also has substance that lends itself to a variety of interpretations and that could give rise to productive questioning. ${ }^{12}$

The Fleurdelisé is official propaganda, but one could reasonably see as it as what right-wing cultural nationalism takes as model history curriculum material, and I will discuss it as such. Although it might not be sufficiently sophisticated for some of them, literate thirteen-year-olds could easily read its narrative; it includes a 12-panel comic of Louis-Joseph Papineau making speeches, with extracts in balloons; it varies its presentation of talking heads by providing maps and announcements of events. It presents dramatic stories of life and death struggles and of a cruel execution, and it singles out heroic figures for more extensive treatment. It attempts to include women, workers, and everyday Catholic priests in the struggle. Suppose, then, that high school history curriculum responded to some of its critics' demands for the study of the key event of the Rebellion by using this publication for the development of a critical enquiry-based mode of investigation. What might students learn? And then how might teachers encourage them to interrogate the material presented critically?

Here is a close summary (not a caricature) of the narrative overview presented in this publication: The national struggle took place mainly in parliament and it was led by four generations of the people's brave and talented leaders, beginning in the $1790 \mathrm{~s}$ with P.-S. Bédard's "war-hardened parliamentary group able to confront the British oligarchy," and able to make the Assembly the main force for democracy. Bédard's was followed by a second generation, led especially by Louis-Joseph Papineau, who throughout his long career "demonstrated a stupefying mastery of the workings of parliamentary institutions." Papineau was especially the incorruptible one, "who refused a seat on the Council, even a minister's post" as long as "the government was not really put in the service of the people and of the French majority." The main battle before 1832 was over government expenditure (the "Civil List"), which the Assembly had the right to supervise under the Constitution, but which Governor Sherbrooke demanded be voted without conditions. Papineau went to England in 1828 and convinced London that the Assembly had the right to vote the Civil List.

The year 1832 was a major turning point. Two journalists were arrested for libel. The English army intervened in a Montreal election and killed three reform supporters in cold blood but no one was ever charged. Then six thousand people died from cholera, creating much anger at England's mad immigration policy. The members of the Assembly voted Ninety-Two Resolutions which were destined to extend the elective principle and to increase their power to combat the corruption that was general among high public officials. People often mistakenly think the Assembly wanted responsible government, but really it wanted American-style republican government.

Why take up arms in 1837? Because the British Empire was not ready to give Québécois more rights. It banned patriot meetings and issued arrest warrants against leaders. Groups hostile to the patriots armed themselves and provoked incidents so that the authorities could smother the embryonic threat of a French-Canadian republic. Unprepared and unarmed, several patriot members of the Assembly nonetheless decided to resist, taking us to the third generation of militants, called the patriots, who would lead the Rebellion and sometimes die for liberty and their Fatherland. 
They wrote the audacious program of the Ninety-Two Resolutions, but relations with Great Britain only worsened. The patriots used all kinds of pressure tactics before finally resorting to armed insurrection to make their voices heard.

A fourth generation appeared after the repression of the Rebellions. The Durham Report of 1840 reunited Ontario and Quebec in order to drown the French-speaking population and to impose Ontario's huge debt on Quebec. Faced with this pestilence, the fourth generation of patriots emerged, called the reformists. They had all been strong Papineau partisans before 1837, "but henceforth they turned their backs on the radical program and agreed to collaborate with the Union regime with Ontario" to save French language and culture and to win responsible government. They got the latter in 1849, but not without once again having to confront the British bourgeoisie. The Parliament in Montreal was burned by the patriots' adversaries who were opposed to responsible government.

Subject specialists will notice that the narrative overview is riddled with errors and imprecisions, but curriculum planners could remove these. Le Fleurdelisé includes more material in a patchwork manner, and makes the claim that all of Quebec, except the English-speaking Eastern Townships, had pro-patriot events, so all municipalities should celebrate them in 2013. It is not worth covering more of the material presented in detail, but the pamphlet does devote half a page to the creation of a second national hero (after L.-J. Papineau) in Chevalier de Lorimier. ${ }^{13}$ De Lorimier is described as a Montreal notary who risked his life first during the Montreal election riot. He was elected Montreal district patriot party secretary in 1837, went to many public meetings, and joined the Sons of Liberty in Montreal. He was injured in the street battle with the Doric Club in November 1837 and was present at StEustache during the battle of December, but managed to escape to the United States, where he helped plan the 1838 uprising. He was present when the Declaration of the Republic of Lower Canada was read at Caldwell Manor in February, and we read that de Lorimier "distinguished himself by taking the manor at Beauharnois, and then by taking the steam boat Henry Brougham without a single shot being fired." He made sure the prisoners were safe before leaving to organize the resistance at Ste-Martine. He tried to escape to the United States, but was arrested and taken to Montreal in cruel and degrading conditions before being hanged.

It might be over the heads of thirteen- or fourteen-year-olds to grasp the notion of genres of historical narrative. If they could do so, their teachers could claim that Le Fleurdelisé presents a conventional nationalist narrative of the sort that appears in many countries: the people, essentially one and indivisible from a time deep in the mists of the past (or at least since 1775) has struggled, without cease, from one generation of leaders to the next, for recognition of its language and culture and for the right to self-determination, against a continually oppressive foreign adversary (who is rather shadowy and tends to change form). Everyone wanted a sovereign republic and there were no significant differences among the people. In the Quebec case, professionally-educated men were leaders and fighters; women cooked, made homespun clothing, and sheltered injured fighters. There wasn't a large union movement yet, but workers in England all supported the patriot struggle, and it would only take 
until 1843 for unionized workers on the Lachine canal to be attacked and killed too. The clergy sold out to the British because it wanted privileges, especially control over schools and links to Rome, but the patriots wanted a secular school system, just like the one we finally won in 1997. And some former patriots sold out in the 1840s and agreed to collaborate with Ontario, where there had been some events in 1837 that didn't amount to much.

One obvious way to encourage critical thinking in an enquiry-based mode would be to provide students with copies of original documents and reports, and to encourage them to search for correspondences and dissonances in versions of events and to compare these with the claims of historians. Teachers could stimulate critical interrogation in this way that would deepen students' basic historical knowledge and their abilities to assess historical claims. The large volume of published Rebellion material, including many original documents, provides excellent resources for such an enterprise and almost any of the claims in the Fleurdelisé could create teachable openings.

So, Chevalier de Lorimier distinguished himself by seizing the manor house at Beauharnois and the steamboat Henry Brougham without a shot being fired? We have a number of eyewitness accounts of these events - including more than one description of them by the same eyewitness - Jane Ellice, whose father-in-law, Edward Ellice Sr., was the seigneur of Beauharnois. There are newspaper accounts, and some descriptions in the "voluntary examinations" of patriot participants by the magistracy after the event. Apart from its other characteristics as testimony, Ellice's has the virtue of being dramatic and exciting.

I would think that one of the earliest interrogations a teacher might encounter would be: "What's a manor house?" And why seize the manor house and why seize a steamboat? And how did the patriots manage to seize them without any shooting? The first question raises the issue of class power and exploitation, about which the Fleurdelisếs account is completely silent, presumably because the people-one-andindivisible can't be class-divided or change its mind about its historical destiny. But the question would immediately create an opening for teaching about the seigneurial system, its semi-feudal property relations, the notion of lord and peasant and so on. A teacher could point out that the manor house was the central institution of local feudal power; that habitants were debtors to the seigneurs and that seizing the manor house meant not only seizing the local power centre, but also typically the rent roll, which could be destroyed. Then, who were the seigneurs? Well, many of them were British like Ellice, but there were some important and powerful French seigneurs too. Well, who? Oh, some very interesting and influential characters: J.-B. Taché, for instance, or Amable Dionne, who made his fortune in salt butter, or perhaps the wealthiest, Joseph Masson, one of the founders of the Bank of Montreal and a pillar of the Montreal bourgeoisie. And of course, there was this fellow, Louis-Joseph Papineau.... Did they all want the end of the seigneurial system and the abolition of their privileges in a republic? Ummmm....

Any number of additional interesting questions might ensue, but many of these would trouble the Fleurdelisês account. Pointing out, for instance, that all the seigneurs had abandoned the patriot party by the summer of 1837 , save Papineau, and 
that even he opposed several planks in Robert Nelson's declaration of independence, since he supported an extension of the seigneurial system, might lead to further investigation of class power in Lower Canada. It would be a short step from there to investigating the economic parasitism of the notaries, many of them patriot leaders, and the role of the tithe in the rural political economy. The presentation of "the people" or the "French majority" as fundamentally one might be questioned. Students might not reject a nationalist account, but their knowledge of historical complexity would be increased.

Like much of the Rebellion literature, the Fleurdelisé is written in the heroic mode. Jane Ellice's diary is instructive for developing a critical awareness in this regard, but other original materials could also provide a more nuanced understanding for students. I certainly wouldn't deny that Rebellion struggles involved acts of heroism, in which some people fought and died for their political beliefs. Even the rebels' adversaries recognized as much: Colonel Wetherall, for instance, the commander who led the British taking of St-Eustache could write to Lord Gosford after that battle — with the patronizing tone of the victor — that "the poor Canadians have more [excessive] courage, than any people, excepting the natives of India, I ever saw - at St-Eustache, they held the Church \& adjoining houses most obstinately." Most of their leaders fled, but not J.-O. Chénier, "a gallant little fellow," who fought to the end and shot himself rather than accept surrender. ${ }^{14}$

On the other hand, students could read the testimony collected in Insurrection, where they would see that many people claimed to have been coerced to come to St-Eustache by armed men; that many were themselves unarmed and fled in terror at the approach of the British and the Volunteers, without firing a shot, only later to have their property burned or pillaged. Teachers need not present this material simply as factual, but could encourage reflection on the conditions under which testimony was collected and how the way it was collected might affect its quality. On the other hand, in reading the diary of Armury Girod, the patriot commander at St-Eustache, students would see a different picture again, one of half-hearted preparation and internal division in the patriot forces. Girod said he had a force of nearly six hundred men at his disposal and wanted to attack Montreal while the British forces were occupied elsewhere, but complained he could not get other patriot leaders to do anything effective. He was particularly scathing of another leading patriot-C.-S. Cherrier. After travelling with Cherrier for a few days in November, he wrote, "it is tiresome to hear this man speak even three phrases - imagine therefore my torture in hearing this eternal babbler make perhaps five long speeches at each corner of the road." Girod was unable to prevent the men under his command from looting St-Eustache in the days leading up to the battle, and he held Cherrier partly responsible: "Cherrier is a lazy and foolish fellow. - his Brother is a drunkard and both cause a deal of confusion through bad example." 15 After the defeat of the first wave of the Rebellion, the leader Robert Nelson complained to his Upper Canadian counterpart William Lyon Mackenzie of divisions among the patriots exiled in the United States, "it is a remarkable fact that the whole unlettered part of Lower Canada is courageous, determined to lose no opportunity to upset British authority, while 
the Catholic-College-educated part of the Canadians are...disposed to accept of any arrangement for their return that will not expose their cowardly skins." 16 Nelson, in other words, did not think the heroes in the struggle were the petty-bourgeois professionals and politicians identified by Le Fleurdelisé.

Part of the point for students, at least as I understand the ends of critical pedagogy, is to render human characters in their complexity, to encourage students to accept that people generally have feet of clay, and, more importantly, to avoid reducing the quality of ideas and doctrines to the moral qualities of the people who espouse them, which is a tendency in heroic history (and as ad hominem attacks in the curriculum debate too). To return to the figure of Louis-Joseph Papineau, who is particularly glorified in the nationalist literature, students could read his correspondence and that of his wife Julie Bruneau and could be encouraged to notice that great men have domestic lives that sustain their greatness and that involve particular kinds of power and emotional relations. Teachers could raise the interesting question of how a seigneur who lived from peasant rent and debt could publicly champion equal rights for all. How could the man who denounced the corruption and heartless cruelty of the English ruling oligarchy derive the major part of his income from renting his sawmills to one of them? How could a professed deist speak publicly in support of the Church and send his sons to be educated by priests? And the questions raised by Julie Bruneau's accounts of her life-her medical treatments during pregnancy, for instance - would likely also be productive in broadening historical understandings. ${ }^{17}$

As to Chevalier de Lorimier, even his political enemies described him as "a young gentleman highly esteemed and of good family," ${ }^{18}$ but how did he distinguish himself at Beauharnois? To make this claim by the Fleurdelisé pedagogically useful, a substantive study of events would be necessary. Students could read Jane Ellice's version(s) of events and teachers could encourage them to think about the ways in which her reactions were shaped by her position as a young upper class woman, commonly addressed as la seigneuresse. ${ }^{19}$ They could compare her diary versions with accounts that appeared in the press and in the writings of contemporaries involved on the patriot side.

Ellice's versions could easily lead one to wonder about acts of distinction at Beauharnois. She suggests that the manor house was unprotected and the rebels blasted away at it anyway without warning or any call for surrender. The steamer Henry Brougham was indeed seized without a shot fired, but it was unarmed as well. It was of no obvious military value and its passengers were not combatants. What was great about seizing it? Ellice claimed to be awakened in the middle of the night of November 3-4, 1838 by a war cry, before the house windows exploded (her French maid was cut by flying glass). Her husband leapt into his clothes and pulled her and her younger sister in their nightclothes to hide in the cellar with the servants. They were soon discovered and her husband and the estate manager were taken prisoner and carried away - she didn't know where. The women "spent an anxious day en chemise, in the middle of a group of the most 'Robespierre' looking ruffians, all armed with guns, long knives, and pikes, without a single creature to advise us, every respectable person in the village being taken prisoner-What a day we passed sitting 
hand in hand, in the midst of a heap of confusion, comforting each other, \& praying for protection to Him who orders all things well. But it was a severe trial - The ruffian looking men coming in every now $\&$ then quite drunk."

Over the next week, Ellice recounts that the patriots pillaged the manor house, with many men getting roaring drunk, shooting, fighting, and racing her husband's horses around the farm. All the passengers from the Henry Brougham, including many women and young children, were crowded into a couple of rooms, probably in the presbytery, and kept there without being able to wash or change their clothes for several days. Ellice claimed she was threatened by patriots who pointed pistols at her, but also that, as time wore on and rumours of relief forces began to circulate, many men came to ask for her protection, claiming they had been forced to participate in the seizure. Ellice had drawing materials and made several coloured sketches of men and events she witnessed; these make her account more vivid, but students might be curious about drawing and sketching. In another passage, she recounted the flight of the patriot forces before the Glengarry Highlanders, and the latter's boasting of how they had burned a six-mile swath on their route to Beauharnois and how they would burn anything missed on their return.

There is much pedagogically useful material here. Accounts of violence and pillage by patriots and by English Canadian Volunteers are numerous: one can easily imagine informed discussions and debates about the conditions for the legitimate use of violence in the pursuit of political change. Lord Durham's prisoner amnesty and exile and Colborne's executions and deportations, alongside accounts of the patriots' murders of Chartrand and Lieutenant Weir (of which particularly graphic descriptions are given by participants and witnesses in Insurrection), could stimulate questions around political resistance, crime and the legitimacy of punishment. The discussions would be deepened by having students discuss the political program contained in Nelson's Declaration of Independence, which the Fleurdelisé reprints.

I think it is unlikely that a straightforward heroic nationalist account of the Rebellions of the kind proposed by right-wing critics of Quebec's reformed history curriculum would survive such scrutiny. And I have only scratched the surface - there remain the issues of the patriots' disenfranchisement of women in parliament; of the opposition of First Nations to the patriot project; and, of course, the very thorny issue of the ways in which the Rebellions resulted in the subordination of French Canada to the Catholic Church for more than a century. Nonetheless, once again my position is that any slice of history or set of historical events could serve as a vehicle for a good secondary school history curriculum, provided teachers expose students to substantial historical materials and encourage critical interrogation from many different points of view.

\section{Conclusion}

Towards the end of their polemic, Éthier, Cardin and Lefrançois note that "the phenomenon of right-wing cultural and identity politics denouncing programs of study that promote the teaching of history from an epistemological point of view, instead of 
being based on patriotism and the transmission of the great national story, has nothing specifically Québécois about it." They show the same phenomenon was present under Howard's Conservatives in Australia, the Thatcherites in England, under Jeb Bush in Dubya's America, and in English Canada with Jack Granatstein's Who Killed Canadian History? ${ }^{20}$

Yet under the current Canadian Conservative government, matters are more serious and more distressing for working historians both professional and amateur, as well as for Canadian citizens generally. Of course, Granatstein's great-white-menblood-and-guts conception of history speaks to part of the Conservative ideological heart. We can see the Conservative government acting in keeping with that vision. Heroic portrayals of war displace accounts of struggles for social justice and equality. Military history colonizes and risks smothering social history.

The government openly pursues a de-Liberalisation of Canadian public space and memory. Royalist culture displaces multiculturalism. At 2013's Canada Day celebrations in Ottawa, on the government jet, in state-funded advertising, Conservative blue and white have driven a formally dominant Liberal red and white out of sight. Orange and Green are nowhere to be seen. There is also the "Macdonaldization" of public space — with the name and figure of the scandal-rocked, alcoholic, wifebeater popping up repeatedly on roads, parks and bridges across English Canada as he is rehabilitated as leading Conservative father of Confederation. We see the obsessively planned and monitored celebration of the bi-centenary of a minor British war, ${ }^{21}$ but complete neglect of the $250^{\text {th }}$ anniversary of the Treaty of Paris, which fundamentally remade the Atlantic world. The Quebec Act of 1774 will also pass uncelebrated - despite the fact that one can argue it provoked the American War of Independence and that one of its by-products was the survival of a French-speaking, Catholic population in what became Canada. And of course the $30^{\text {th }}$ anniversary of the Charter of Rights and Freedoms was not officially recognized. The Conservative backbench moved formally in 2013 to institute an enquiry into the teaching of history in the nation's classrooms, hesitating only somewhat when it was pointed out that education is a provincial responsibility. ${ }^{22}$

All of that can be seen as another version of the right-wing nationalist memorymaking that Éthier, Cardin and Lefrançois criticize. But the Conservative government has been doing something which governments in liberal democratic societies rarely do: it has been systematically destroying established resources and infrastructures across a great many scientific fields, history among them. Capacities for historical research now are being eliminated and steps are being taken to prevent future historical research in many areas of enquiry. The process is multi-faceted, progressing rapidly and far from complete: I don't pretend to capture it here. Readers can await the results in 2014 of the Royal Society of Canada's special investigation into the fate of Library and Archives Canada, but users of this central research resource can notice already dramatically increased difficulties in getting access in a timely fashion to documents and records. Archive subject specialists have been eliminated and a muchreduced staff of archivists now floats across record collections, limiting its expertise. Inter-library loan programs have been ended at the same time as government has cut 
funding for local historical societies. Particularly striking is a continuing digitization project, which offers no long-term guarantees for the preservation of records, and which the Conservative government plans to fund in part by licensing a consortium to provide Canadians with access to our own documentary heritage - for which we have already been taxed - for a fee.

The French-language literature has the advantage of containing a heated debate that engages a fairly wide-spectrum of intellectuals and activists, in contrast to the much more muted discussion of the current federal government's remaking of history. The Quebec nationalist memory project has multiplied available historical resources - selectively, usually with an ideological overburden, and perhaps at the expense of English historical memory in Quebec - but substantively nonetheless, in a well-established tradition of historical inventory-making. While weekend readers of "Canada's National Newspaper" - The Globe and Mail - are treated to Margaret Wente's ditzy, gossipy and occasionally original opinion pieces, readers of Le Devoir get full-page spreads such as Simon Couillard's essay on how the philosopher Paul Ricoeur would go about teaching history. ${ }^{23}$ Éthier, Cardin and Lefrançois rightly point out that the French-language press frequently indulges in mindless, hot-button history panic talk, but their polemic itself demonstrates the richness of the contemporary debate in Quebec.

\section{Notes}

1 I increasingly agree with Rogers Brubaker, "The Manichean Myth: Rethinking the Distinction Between 'Civic' and 'Ethnic' Nationalism," in Hanspeter Kriesl, Klaus Armingeon, Hannes Siegrist and Andreas Wimmer, eds., Nation and National Identity. The European Experience in Perspective, (Zurich: Verlag Ruegger, 1999), 37-54, that the distinction between civic and ethnic nationalism lacks sufficient analytic precision to be of much use. Both civic and ethnic nationalism could consistently demand that political life in Quebec be conducted in French, for instance. It also carries a crippling moral overburden, which leads to the "civic" being seen as virtuous, and the "ethnic" as inherently malign. Brubaker proposes that we distinguish nationalist movements instead according to whether they are state-sponsored or state-opposed.

2 Geo-politics plays some role in these matters as well, as recent French governments have attempted to reclaim Quebec as part of their own national heritage and as Quebec's cultural outposts pop up in such French cities as Bourdeau and St. Malo. See Darryl Leroux, 'Commemoration and Images of the Nation in the Quebec 400,' (Unpublished Ph.D., Sociology, Carleton University, 2010).

3 André Lecours, "Ethnic and Civic Nationalism: Towards a New Dimension," Space \& Polity, 4 (2000), 153-165. The most visible provincial party on the left, Québec solidaire, is also nationalist, but has yet to make a major electoral breakthrough.

4 This argument is an interesting inflection of the standard orthodox religious argument about secular instruction that the episcopal churches invoked in $19^{\text {th }}$ Century Lower Canada. I discuss this matter in several places in Ruling by Schooling Quebec: Conquest to Liberal Governmentality. A Historical Sociology (Toronto: University of Toronto Press, 2012).

5 The list sometimes carries other qualifications: "the Conquest", "the patriots' war", the Durham betrayal and the sell-out of the moderates, such as Étienne Parent, A.-N. 
Morin, and L.-H. Lafontaine, and finally various federal betrayals, in a justificatory narrative of victimization.

6 See Michèle Dagenais and Christian Laville, "Le naufrage du projet de programme d'histoire <nationale $>$. Retour sur une occasion manquée accompagné de considérations sur l'éducation historique," Revue d'histoire de l'Amérique française, 60 (2007), $517-$ 550. Félix Bouvier, "Retour sur le projet de programme d'histoire <nationale > et son éducation à la citoyenneté," Revue d'histoire de l'Amérique française, 61 (2007), 261270. Robert Comeau and Josiane Lavallée, "Réplique à l'article de Michèle Dagenais et Christian Laville," Revue d'histoire de l'Amérique française, 61 (2007), 253-260. Michèle Dagenais and Christian Laville, "Un coup d'épée dans l'eau. Réponse à la réplique, avec une postface," Revue d'histoire de l'Amérique française, 61 (2007), 271-279.

7 This re-naming is the latest in a series of shifting iterations; see Jean-Paul Bernard, ed. Les rébellions de 1837-1838: Les patriotes du Bas-Canada dans la mémoire collective et chez les historiens (Montréal: Boréal, 1983). Historians will recognize the active invention of tradition in the Rebellion memory project; see Eric and Terence Ranger Hobsbawm, eds, The Invention of Tradition (Cambridge: Cambridge University Press, 1983). In the interests of disclosure, I was a consultant for the exhibition, "Rébellions 1837-1838: Patriotes vs Loyaux” organized at Pointe-à-Callière, by the Musée d'histoire et d'archéologie de Montréal.

8 Robert Christie, A History of the Late Province of Lower Canada. Parliamentary and Political. From the Commencement to the Close of its Existence as a Separate Province, 6 vols. Vol. 4 (Montreal: Richard Worthington, 1866), 393 on the Te Deum. Allan Greer, The Patriots and the People. The Rebellion of 1837 in Lower Canada, (Toronto: University of Toronto Press, 1993). Public Record Office of Northern Ireland (PRONI) D2259/8/49, Wetherall to Gosford, 7 August 1837, “That vagabond Papineau would not join the procession to proclaim the Queen."

9 Jocelyn Létourneau, "Pour un autre récit de l'aventure historique québécoise," in Damien-Claude Bélanger, Sophie Coupal and Michel Ducharme, eds., Les idées en mouvement: perspectives en histoire intellectuelle et culturelle du Canada, (Québec: Les Presses de l'Université Laval, 2004), 64.

10 Movement national des Québécoises et Québécois, Le Fleurdelisé (Montréal, 2207, rue Fullum, printemps, 2013). As partners, the group claims the Province's two main trade union organizations, the CSN and the CSQ, the Fondation Lionel-Groulx, the APHCQ — an organization of college history teachers — and the leading nationalist history publishing house, Septentrion. In association with many local branches of the Société St-Jean-Baptiste, the group was involved in the coordination of events for the 2013 patriot's day celebrations.

11 Gilles Laporte, Patriotes et Loyaux. Leadership régional et mobilisation politique en 1837 et 1838 (Québec: Les éditions du Septentrion, 2004). There are youtube videos available of some of Laporte's speeches.

12 For instance, Philippe Bernard, Amury Girod. Un Suisse chez les Patriotes du BasCanada (Sillery: Septentrion, 2001). Gérard Filteau, Histoire des Patriotes. Introduction de Gilles Laporte (Sillery: Septentrion, 2003). Julien S. Mackay, Notaires et patriotes. 1837-1838 (Sillery: Septentrion, 2006). Marcel J. Rheault, and Georges Aubin, Médecins et patriotes. 1837-1838 (Sillery: Septentrion, 2006). Often the same material is reproduced, but cut up in different ways in these inventories. Especially valuable are the two volumes, Georges Aubin and Nicole Martin-Verenka, eds., Insurrection. Examens Volontaires. Tome I 1837-1838 (n.p.: Lux Éditeur, 2004), and Insurrection: Examens Volontaires. Tome II: 1838-1839 (Montréal: Lux Éditeur, 2007). These have transcribed and collected the vast majority of testimony by those interrogated in "voluntary examinations" by magistrates in relation to their involvement in insurrectionary events. 
13 I note that the hanging of a number of rebels was part of the military government's response to the Rebellion of 1838, and de Lorimier's case was particularly moving, especially because of Lady Colborne's mercenary rejection of his wife's pleas for clemency, which isn't discussed in Le Fleurdelisé.

14 PRONI, Gosford Papers, D2259/8/56, Wetherall to Gosford, 21 December 1837.

15 LAC (Library and Archives Canada), MG24 A27, 34, Diary of Amory Girod (in translation), 19 November, 6 December 1837.

16 Archives of Ontario, Mackenzie-Lindsey Papers, Nelson to Mackenzie, 21 July 1838, quoted in Elinor Senior, Redcoats and Patriotes: The Rebellions in Lower Canada, 183738 (Ottawa: Canada's Wings, 1985).

17 Claude Baribeau, La seigneurie de la Petite Nation, 1801-1854: le rôle économique et social du seigneur (Hull: Éditions Asticou, 1983). Yvan Lamonde, "Conscience coloniale et conscience internationale dans les écrits publics de Louis-Joseph Papineau (1815-1839)," Revue d'histoire de l'Amérique française, 51 (1997), 3-37. Yvan Lamonde, and Claude Larin, eds., Louis-Joseph Papineau. Un demi-siècle de combats. Interventions publiques (Montréal: Fides, 1998). Julie Papineau, Une femme patriote. Correspondance, 1823-1862 (Québec: Septentrion, 1997).

18 Robert Christie, A History of the Late Province of Lower Canada. Parliamentary and Political. From the Commencement to the Close of its Existence as a Separate Province. 6 vols. Vol. 5 (Montreal: Richard Worthington, 1866), 272n.

19 Of course, unilingual Francophone students would need a translation, but the diary has been published in English: Patricia Godsell, ed. The Diary of Jane Ellice (n.p.: Oberon Press, 1975). I say "versions" because she recounted events to herself at least twice in the diary, adding and correcting information - a pedagogically interesting subject in itself.

20 It was Timothy Stanley and he did it on purpose. Timothy J. Stanley, “"Why I killed Canadian History?: Conditions for an Anti-racist History in Canada," "Histoire socialel Social History, 33, 65 (2000), 79-103

21 "'Little known war' a big deal for Ottawa", Globe and Mail, 27 April 2013: the Prime Minister's Office apparently obsessing even about the colour of Laura Secord's cloak in its advertising efforts.

22 “Tories to review Canadian history curricula", Ottawa Citizen, 3 March 2013.

23 Simon Couillard, "Paul Ricoeur et le caractère politique de l'enseignement de l'histoire", Le Devoir, 12 May 2013. Couillard attempted to argue that some historical events, such as the Conquest, stimulate lively interest on the part of people because they are objectively important to the national community (whose symbols and traditions the state has an obligation to protect), while others, such as the War of 1812, leave people indifferent because they are unimportant to that national community. But this position, among other things, assumes a homogenous national community and a state whose interests are identical with it. Precisely the problem for the fabrication of historical memory in both Canada and Quebec is that neither of these conditions obtains. Moreover, what is important to people in terms of historical memory and tradition is a result of work done to make it important, which returns us to the problem of what events, if any, to make important and which to ignore? 